\section{7. 間接的指動脈血圧連続測定装置}

\section{東医歯大 医器材研}

松本仁志山越憲一 島津秀明庄司孝雄 戸川達男

植田製作所

鳥井嘉彦＼cjkstart植田和夫

種々の生理的，心理的負荷に対する血圧の早い応答 結果を得たい場合，聴診法を用いた従来の間接血圧測 定法では，一回の測定に時間を要し，適当でない，こ れに対し，光電脈波とカフにより， systolic end point を追従制御して，一拍ごとの最高血圧值を測定 記録する装置が市販されているが，この方法では最低 血圧はもちろん血圧波形をも得ること法出来ない，こ れらの方法に対し，演者らは，指を用いその動脈血管 床容積を一定にサーボ制御して閒接的に指動脈血圧を 連続測定できる方法を考案し，その装置についても昨 年の本学会で報告した。今回この装置に改良を加え， より安定に，比較的長時間指動脈血圧を連続測定でき る装置を新たに考案，試作したので報告する。試作装 置の主な構成は，カフが内蔵された透過式光電脈波装 置, カフ内圧を流体容積で制御するダイヤフラムアク チュエータこのアクチュエータを作動する加振器, お よび指の光電脈波を検出・堌幅して加振器を動作させ るためのパワアンプから成る, サーボ回路 構成であ る.この一巡閉ループ系で，指血管床容積に対応した 光電信号を一定值にクランプすると, 血管内圧変化, すなわち動脈圧変化に対応した圧変化がカフ内圧変化 と平衡し，カフ内圧を測定することにより，間接的に 指動脈圧を求めることが出来る．試作装置の周波数特 性は $60 \mathrm{~Hz}$ （飠断周波数）で，血圧測定に十分な性能 を有している．本装置を用い，ラット尾を用いた動物 実験および実際に正常血圧患者, 高血圧症患者でカテ 一テルによる直接法との比較実験を行なったところ, 本法は $5 \%$ 以内の精度で血圧測定が可能で，種々の負 荷試験に対する血圧忘答結果も極めて良好な成績を得 た. 本装置は非観血・無侵襲的にカテーテル法と匹敵 する確度で瞬時血圧測定が可能であり，早い血圧応答 結果を得たい場合とか，新生児，乳幼坚などカテーテ ルを挿入し難い患者には非常に有用であると思われ る.

\section{8. テレメータリングアドミタンス・プレ チスモグラフ}

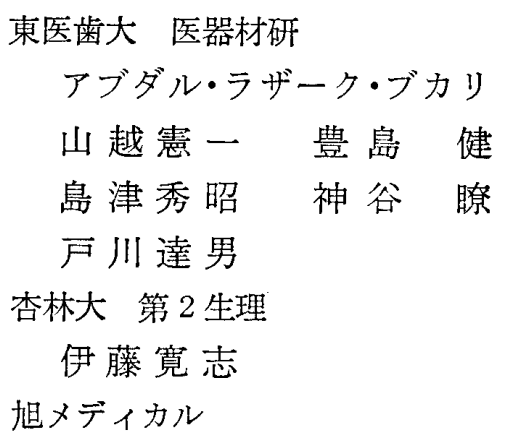

藤崎誼達

電気的プレチスモグラフ法による血流計測は，その 無侵熋性，簡易性，測定に特殊な技術を要しないこと など，奏用性の高い方法であることが多くの研究者に より確認されている，演者らはこの方法の中，特にア ドミタンス法が，生体血流計測に非常に有効であるこ とを示し，本法を用いた監視装置および臨床使用結果 などについて本学会でも報告した。 しかし本法を臨床 分野以外，例えば労㗢医学，リハビリテーションなど の分野に適用するには，測定場所が限定されず長時間 モニタができ，コードレス化された計測装置が望まし い，そこで今回，コードレス化を目的として，胸部ア ドミタンスおよび四肢アドミタンスプレチスモグラフ イによる心拍出量㧍よび四肢血流計測に適用できるア ドミタンス・バイオテレメータを開発したので報告す る。試作テレメータは，四電極法で生体アドミタンス を測定し，得られたデータ（平均全アドミタンスY拧 よびアドミタンス脈派 $\Delta Y$ ）を心電図ととも汇無線送 信する送信機，及びこれらのデータを受信・処理する 送信機から成っている，送信方法は，PDM/FM 変 調方式を採用し，Y， $\Delta \mathrm{Y}$ および心電図法時分割多重 化されたパルス幅変調信号でFM送信される。受信機 ではこの多重化変調信号を復調し，パルス幅に比例し たアナログ電圧信号を得，感度調節後データを記録す る.この際心拍出量測定に必要な $\Delta \mathrm{Y}$ の一次微分 $\mathrm{dY} /$ dt は, 内蔵した微分器で得られるようになっている。 また四肢アドミタンス計測では, 動脈性容積脈波に比 例した $\Delta \mathrm{Y}$ 信号が得られると同時に，静脈圧迫法との 併用で，静脈圧迫に伴らアドミタンス変化をY信号か ら得, 当該測定部の血流量を得ることも出来る. 試作 送信機の形状は， $150 \times 100 \times 50 \mathrm{~mm}$, 重さ $200 \mathrm{~g}$ で, 使用電池はアルカリ乾電池 4 本を用い，24時間連続使 用可能である。測定範囲は屋内 $50 \mathrm{~m}$ ，屋外で $100 \mathrm{~m}$ 程 度であり， 2 \%以内の確度で生体アドミタンス信号を 送受信でき，種々の研究分野に有効に適用できること 
が確認された。

\section{9. 無拘束間接的連続血圧測定装置}

早大理工学
庄司孝雄 土屋喜一
東医歯大医器材研
山越憲一島津秀昭
神谷 瞭 戸川達男
横浜市大第 2 内科
㭊久保修

〈はじめに〉血圧値流日常生活のなかで微妙に変動す るた放，その長時間連続測定の意義涂極めて大きい， 演者ら浽前額側方上部に装着した脈波検出器で検出し た光電脈波と，同一個所に固定したカフの内圧制御と により，浅側頭動脈前頭枝の最高及び平均血圧を被験 者を拘束すること無く間接的汇長時間モニタする装置 を考案・試作したので報告する。

〈測定装置及ひ方法〉試作装置注被験者の心藏位置に 装着された検出・送信部とデータを受信・処理する受 信・苔録部とから構成されるテレメータソング方式を 採用した. 光電脈波検出器流小型の液体封入カフ内に 郝外領域の発光ダイオードと, 受光素子としてフォト トランジスタを同一面上に組込んだ構造で，被験者の 浅側頭動脈前頭枝上の皮膚任装着具で固定する。送信 部に内蔵された小型液体ポンプにより設定圧（予想さ れる最高血圧より 20 30 $\mathrm{mmHg}$ 高い值) までカフ加 圧を行なう。このときのカフ内圧の上昇法送信部内の 圧力センサで検出され，同時に検出した浅側頭動脈前 頭枝の光電脈波とともに送信され，これら深受信・記 録部で記録される．脈波信号はカフ内圧の上昇ととも にその振幅が大きくなり, 次いで減少し始め消失す る。これより各血圧值の決定㳘，振幅が最大となった 時点のカフ内圧を平均血圧, 脈波の消失した時点のカ フ内圧を最高血圧とし，血圧値のモニタを行なった。 以上の操作が適当な時間間隔で繰り返され，連続測定 が行なわれる。

〈結果と検討〉試作装置で長時間連続測定した浅側頭 動脈前頭枝の間接血圧値と，同時に聴診法で測定した 上啘動脈の血圧值は良く対応し，本法法長時間の血圧 測定に有効であることが確認された。本装置では被験 者を拘束することが無く, 日常生活時, 軽い運動時な どにも適用でき, 被験者の舆時閒にわたる循燷状態を 把握する上でも有用であるう。

\section{0. 末梢脈波センサーによる末梢循環モニタ リング}

\author{
東大 第 2 外科 \\ 山崎善弥 \\ 高浜龍彦 \\ 藤森義蔵 \\ 医歯大 医器材研 \\ 島津秀昭 \\ 戸川達男
}

消化管手術において，安全な手術を施行するた内に は，有茎胃腸管の生着が可能か否か，また吻合部の治 㽷が血行の面からみて理想的に行われるかどうか，荻 屯腸管の整復後生存し得るかどうか, 腸循環障㝘の判 定はきわめて重要である，従来外科医は腸管所属動脈 の膊動, 静脈うっ滞の程度, 腸管自体の色調などで判 定を行っておうり，経験的で戦密な判定規準は不明確で ある．そこに腸管グラフトの血行状態が，動脈の逆流 圧の測定, 所属静脈の $\mathrm{PH}, \mathrm{PO}_{2}, \mathrm{PCO}_{2}$, 組織 $\mathrm{PO}_{2}$, 腸 管グラフトの温度分布衫よびサーモグラムなど客観的 情報により判定されるかどうか比較検討し，腸管サ一 モグラム的手法が最も容易で確実であることを認め た。 しかしいずれも簡便且つ即座に腸管末梢血流状態 を判定するには問題を伴った。そこでわれわれはプロ ーブを計測部に密着させるだけでよい未梢脈波センサ 一を開発した。

本装置浾外領域の発光ダイオード（Ｉ C N 103） 5 個およびフォトトランジスタ（T P S 603）4 個よ り構成されるセンサー（外径 $20 \phi ，$ 厚さ $10 \mathrm{~mm}$ ) を体 表面あるい法藏器に密着させて, 測定部位の動脈内血 液容積変化化伴 万反射光量の変化を検出寸るものであ る. 基本的に泣指尖光電脈波法の灾用であるが，谜来 の指尖光電脈波計が指尖の動脈性脈波しか検出できな いのに対し，本装置で泣頭部浅侧頭動脈，手掌，足背 など浅在性末梢動脈など体表層部にある活とんどの動 脈，ならびに開腹時において，雸，大腸，小腸，肝臓 などの大小動脈系の脈波検出が可能である。本装㯰は センサー部はもちろん，本体も非常に小型（80x60× $20 \mathrm{~mm}$ ) であり，本体ごと減菌可能であり，電源も電 池使用であるため，手術中の使用に際して安全であ る. 本装置の実際検討により腸管グラフトの血流状態 判定に充分有用なことを実証した，四肢血流障害部位 の判定などの末梢循環モニタリングへの広い応用が期 待される。 